\title{
Educational Transformation through whānau (or marae-a-hapū if you prefer): The centre of our universe
}

This chapter is dedicated to the late Danny Hona without whom, this work would not have been possible and who despite his departure, continues to stay engaged in the struggle conducting from another space. This article highlights the principle of hoa haere or valued travelling companions as it shares the report of a group of like-hearted kaiako and our evaluation of the pedagogy that was undertaken in the delivery of an indigenous-based bi-cultural programme in social work in Aotearoa New Zealan - He Tohu Paetahi: Ngā Poutoko Whakarara Oranga, BSW (Bi-culturalism in Practice).

Additionally, the findings of this report were presented at the 2014 Joint International Association of Schools of Social Work, International Federation of Social Workers and International Council on Social Welfare Conference in Melbourne.

\section{Background}

In 2012-2013 an evaluation of the Te Wānanga o Aotearoa social work degree programme Te Tohu Paetahi: Ngā Poutoko Whakarara Oranga BSW (Bi-culturalism in Practice) was conducted at the Tauranga campus. In particular, we wanted to explore the critical indigenous space of marae and how Noho maraebased wānanga delivery might enhance tauira learning through their relationships with this space and their engagement with tribal epistemologies, in a bi-cultural social work programme. Also how this pedagogical approach might provide opportunities for contextualisation of nga takepu and tikanga in its authentic state.

Taina and Hariata Pohatu in their fashioning of this degree programme positioned social work as being grounded in relationships with people and kaupapa in pursuit of mauri ora. The philosophy according to the programme document $(2013$, p. 33) "centres on understanding human relationships and their cultural legacies in the pursuit of mauri ora". Ngāti Awa kaiako Danny Hona was an accomplished practitioner of this wisdom. He was committed to his cultural obligations and responsibilities to take care of relationships as being central to who he was. Towards this end he positioned himself in the marae space as the Kaitiaki (caretaker) of the mauri. In his own words:

\begin{abstract}
Putting it simply, I am a Ngāti Awa person working in the industries of education and social work and therefore my Ngāti Awa knowing, is fundamental to my behaviour and ensuing engagements with others within either context. For most indigenous peoples, our indigeneity is acknowledged as fundamental to our responsibilities to engagement as the first step to a relationship or what Maori tend to stress as whakawhanaungatanga.
\end{abstract}

As hoa haere or valued travelling companions, the intent for this endeavour, was to provide an opportunity for both kaiako and tauira to share some of their perspectives and experiences of the marae as a teaching and learning space and method within this programme. This work is a representation of some of these shared stories.

Working in the social services, it is apparent in the disproportionate negative statistics that indigenous peoples continue to endure, that the effects of colonisation still remain. Within the profession, it is therefore important to contribute to initiatives and practice that supports recovery from the ongoing impacts of colonisation. The bi-cultural framework of this degree programme recognises the historical foundations of Aotearoa New Zealand and that Maori bodies of knowledge must accord equal space in every aspect of the learning, thinking and training processes, alongside their non-Maori counterparts. To best facilitate this occurring, our team transitioned the program delivery from classroom based to marae based delivery.

A marae is a communal or sacred place that serves religious and social purposes in Aotearoa New Zealand. Similar structures also existed in other parts of Polynesia; however, most of these marae were destroyed or abandoned with the arrival of Christianity in the 19th century (Haerewa, 2017). Here in Aotearoa New Zealand however, Maori have been able to maintain the marae as a waahi tapu, a sacred place of significance

Many, if not all marae would have been imbued with mauri sanctified by ancient karakia conducted by tohunga. Ranginui Walker (1990) describes the marae as "the focal point of Māori culture and communal activities" (p. 90). His ideas are further endorsed by Ohia, (2006) in his assertion that marae have always been amongst other things, the central point of organisation, communication and networking for Māori, the places where the Māori language and tikanga continued to be used and where the protocols, whakapapa and relationships were preserved. 
The marae not only facilitates equal space for bi-cultural education but it could be said begins to facilitate some balance to the teaching and learning of eurocentric education, which has not always served Maōi, and many of those who choose to study at Te Wānanga o Aotearoa, well.

A Ngāti Awa/Tūhoe tauira talked about his experience of being comfortable at the marae as it provided a space and a feeling which put him at ease because of his familiarity to its processes and because according to his description, "a typical pā boy from Texas". He felt that the marae privileges the benefits of collective sharing and learning through wānanga pedagogy, as opposed to the limitations of individualised classroom pedagogy. This provides a significant point of difference to that of "the classroom". The marae as a teaching space brings with it tautoko and awhi which are an integral process of collective learning.

A tauiwi tauira had this to say about the marae setting:

When you take your learning environment outside of the 'white box' into someone else's protocol [tikanga], that is a massive shock for the first time. I've never done this in my life, and I have lived in this country all of my life. All of a sudden you start to understand that there is a different way, that it is vitally important for us to be here and to live as good neighbours, as good guests and that we're invited and that it is alright, you don't have to be scared. It's okay. (Tauira: Year 3 tauira, 2012)

The Ngāti Awa/Tūhoe tauira appreciated the marae as a learning space because it was one they were comfortable with, but also recognised the importance of this space for learning, individual and collective. The tauiwi tauira shares the revelation of what it is like for many who have never been to the marae and therefore may have a fear of no knowing and not feeling comfortable. They challenge themselves about being neighbours and yet not really knowing each other. Moving outside of the white box and putting your trust in this situation is one that you should not be afraid of. Interestingly, this situation is presented by a tauiwi tauira, but is also the position of many of our Maori tauira, who may have been removed from marae life or from knowing themselves as Maori. All is answered at the marae.

All of these views were common across the range of tauira across the three years in the programme as they came to recognise the indigenous space of the marae as a natural site of learning, holistic and inclusive representation of Maori culture and identity with its own framework, its own set of rules.

As for learning in the noho base, I don't want to go back into the classroom. If I did it independently, I would probably fail, whereas in the Wānanga I can feed off everyone, tauira and kaiako (Tauira: Year 1, 2013)

On the marae, tauira share a deeper sense of connectedness to each other, one where they feel supported on their learning journey. This energises and activates them to take a leap of faith, to believe that they can contribute and support others. Tautoko asks them to step up and step forward in this space, and while tauira may also have to come to terms with navigating tensions, it is also about collaboratively looking for solutions. Tauira quickly readjusts to the understanding that Wānanga pedagogy is not a spectator course and you are not permitted to just talk about support, but one where you are encouraged to demonstrate the heart, the mind and physical applications of tautoko.

Ngāiterangi, Ngāti Ranginui Kaiako Tania Tutaki endorses her learning of the significance of the marae as tautoko to tauira learning in the following statement:

\begin{abstract}
Part of this learning journey is to understand the marae setting has an ancient life force of its own embedded over centuries as part of the continuum of ancestral knowing and hence a supportive environment already exists. The environment of the marae enables theory and practice to manifest through experiential, and mindful engagement. The marae environment is in itself the principle tautoko for these engagements to occur.
\end{abstract}

Within our marae teaching delivery space, the teaching team recognised the inclusion of wairuatanga is what permeates everything we do. Spirituality, conscious or unconscious knowing, is what connects us together in the one shared space. The presence of the spiritual world to the physical world, whatever one's faith, is integrated into the epistemologies of this programme, both in its delivery and its teachings. This creates āhurutanga, a safe space where tauira can bring their own spiritual values, and beliefs to the centre without feeling whakamā or threatened.

This is not a (k)new way of teaching or delivering, as Maori have been engaging in this form of education/wānanga for over 900 years. McLennan $(2010$, p.10) supports this notion in his assertion that, "spiritual direction in cultural situations calls for the acceptance of difference of spiritual perspectives, suspension of judgement and simple curiosity to provide a trusting environment."

Wairuatanga/spirituality in our space is then not about a religion or more specific, the laws of religion, it is about a way of life that intertwines, infuses and influences the nature of life and what it means to be human (Williams, 2008). When coupled together, these two concepts, life and humanity, can be described as a force that opens doors for knowledge and understanding to flow. Marsden (2003) states that "when the illumination of the spirit arrives in the mind of the person, understanding occurs, for knowledge belongs to the head and knowing belongs to the heart" (p.79). 
Ngāti Ranginui Kaiako Reona Anderson further endorses the significance of wairuatanga in her observation:

Kaiako and tauira who engaged in our delivery of social work education, not only get to experience this new way of learning and engage in principles and processes of tautoko and spirituality. They also get an opportunity to become part of a movement, a counter-hegemonic movement that is transformative not only in its delivery of social work but also within their own personal lives.

As a teaching team, we held the belief that social work educators must help decolonise our profession. In the development of the degree programme, six (6) Māori centred principles were introduced by Taina and Hariata Pohatu, supported during this time by Rory Truell, in the development of the degree programme. These six principles/takepū offered a framework to guide best social work practice in Aotearoa New Zealand and to 'best practice' internationally from a Maori knowing. They are as followed:

- Tino rangatiratanga: absolute integrity in uniqueness,

- Whakakoharangatiratanga: respectful relationships,

- Āhurutanga: safe space,

- Kaitiakitanga: responsible stewardship,

- Taukumekume: the interaction between positive and negative tensions,

- Mauri Ora: well-being (Pohatu, 2008, p.5).

These principles provide a Māori framework from which to make sense of ourselves and our accountability and/or obligations in our practice, in any given context. Monty Ohia (2006) supports this notion but describes this as spiritual and ethical moral imperatives. He goes on to state that:

\footnotetext{
...the moral dimension must include 'integrity', 'honesty', 'moral maxims', 'ethics', virtuosity' and 'goodness' as bottom-line requirements of behaviours in all society, not solely in individuals. The ethical imperative, on the other hand, he says, requires that all choices and decisions made are fair, justifiable and right.
}

So, in broad terms, arguably, the moral imperative requires a moral basis to inform the lifestyles of individuals and the behaviour of collectives and the ethical imperative requires ethical determinants, processes and resolutions upon which decisions can be made (p.163).

Ohia, very much like Pohatu, believed that through Maori or any other culture, embracing these imperatives or principles, transformation can occur.

\begin{abstract}
Ngā Takepu - from the beginning when we come in through pōwhiri - we become familiar with the environment, and it creates āhurutanga (safe space) for us. We gradually become comfortable and relate to each other, we begin to develop whakakoharangatiratanga (respectful relationships). We have our taukumekume (tensions) within learning, and as kaitiaki (responsible stewards) we support each other along the way to alleviate those tensions, all striving for the same thing, Mauri Ora (well being). That's what we share with each other. (Tauira: Year 2, 2013)
\end{abstract}

This tauira was from Ngāiterangi, and his experience of marae shows the intimate levels of responsibility that are developed through an understanding of takepū. This was typical of the feedback from many of the Maori participants, including those Maori tauira where the marae was not a familiar space. An acceptance of whakapapa (genealogy) and belonging began to occur on the marae. They drawn to, and connected to a mauri provided to them in this space, a concept that is not always explainable, and would often start another journey of learning for tauira. Another journey where they were finding themselves, where the spirit or the wairua was being nourished.

Just as important as it is for Maori to be able to use their own knowledge as a basis for a curriculum that enables them to work with their own in the social work context, there is also the question of how those who are not Maori might be able to make contributions of consequence given this body of knowledge to a principled, bi-cultural degree?

With this in mind, Lynda Coley shares her learning as a Pākehā kaiako in the teaching team:

\footnotetext{
I have come to realise that taking care of our relationship with the indigenous people in whose lands we live is a central tenant to social justice. How we treat each other in our individual uniqueness, genealogy and sovereignty are framed in this degree as the principle of Tino Rangatiratanga. It allows for the moral imperatives of honour and integrity, and it allows space for all non-indigenous people to take responsibility for their role in the redistribution of power. When I take responsibility for being in companionship with indigenous people, I expose myself to a whole different cultural truth and social order, never more apparent than in marae.
}

Learning that is beautifully endorsed by the following reflection from a non-indigenous tauira: 
I guess for me having [noho wānanga] set at the marae was huge ... because you are actually placing the indigenous culture at the centre and you are learning and comparing the two from that indigenous knowledge base. The context had to be right for bi-cultural learning to take place ... being in the marae environment is not only a head but a heart understanding.

(Tauiwi tauira: Yr 3, 2012)

Relationships are critical to ensuring that learning occurs. As indicated in these comments, non-Maori may need to consider what "placing the indigenous culture at the centre" means in terms of the redistribution of power. Marae, as a critical learning space, that while different from their own, offers a unique contribution to becoming bi-cultural practitioners. This space offers learning that is both physical and non-physical, something that is not always evident in a classroom. Within and around the Marae, the learning is on the walls, it is in the stories that are told, it is about being connected to the land and the people who are a part of this place. Both kaiako and tauira experiences shared here indicate that trusting in this relationship exposes non-Maori to a whole different cultural truth and social order, and potentially rectifies an imbalance, allowing for healing of both parties to occur.

It may not always be a comfortable space, but it offers a unique and meaningful opportunity for healing, for learning and for growth. The intention of which, ultimately, each of us comes to have an understanding about self, our position in Aotearoa New Zealand and the critical relationship between Maori, and nonMaori. This in turn incites active participation in individual wellbeing and collective wellbeing, an understanding that the personal is political, and that social justice is critical to being in Aotearoa New Zealand and in social work.

The marae offers a place for healing as noted by this tauira:

I am a much better parent, mother, daughter, cousin and niece because I came into a place of learning of who I am. I learnt to let go and no longer believe that negative stuff about me. It's not true ... I let it go and allowed myself to heal. I understand that the way to truly change the places and spaces we occupy, is to do it in alofa. (Tauira, 2012)

The Marae also offers a space for kaiako to model biculturalism in practice and additionally, what is required to work confidently and appropriately in this space. The following comments reflect on observations made by some graduates:

A principled Pākehā kaiako is a kaiako who has reconciled with their own journey. They have accepted that they are Pākehā and they don't feel guilty for being Pākehā. One who comes from a place of peace with their journey and understanding of where they stand now... is someone who has gone through the white privilege journey and come back to a place within themselves in their own light (Graduate 2013).

\begin{abstract}
A lesson about reciprocal relationships and respect that can actually work. Because we actually have two kaiako that are Māori and Pākehā and can talk and listen to each other, this encourages other people to do that (Graduate, 2012)
\end{abstract}

From a kaiako perspective these graduate observations are further endorsed by Lynda Coley:

\begin{abstract}
I have learned that I really need to get over myself ... that my way of being is not the only way ... that there is richness beyond the privileging of whiteness. The principle of Te Whakakoharangatiratanga considers that how we regard ourselves informs our respect for others in all of our relationships. It invites us to uphold the moral imperatives of integrity and goodness in all our contributions to relationships.
\end{abstract}

Johnston (1998) suggests that navigating the power relationship between Māori and Pākehā parties is a critical component of biculturalism, and in this instance relevant to a bi-cultural, counter hegemonic positioning of social work education. Graham Smith (2003) believes that the purpose of colonisation is to stifle and diminish Maori imagination, vision and ability. He states that the 'politics of distraction' ensures that colonisation keeps indigenous people's thinking that they are 'always being on the back foot, having to explain, be accountable for and answerable to the coloniser. The logic of the distraction strategy is to keep the indigenous people caught up with having to constantly respond, explain and justify authentic ways of being, that are different to do the dominant culture. This fits well with Gramsci's notion of hegemony;

Hegemony is a way of thinking - it occurs when oppressed groups take on dominant group thinking and ideas uncritically; even though those ideas may, in fact, be contributing to forming their own oppression (Smith, 2003, p. 3). Danny Hona shares a profound example of this in sharing his own story:

The price of being a Maori has been phenomenal in my life, with the burden of people's perceptions and their demands of expectation overwhelming. The hidden agenda of my cultural design has been damaging to my own sense of security and my true sense of belonging. Mr Timbrell's (my primary headmaster) message to me as a child, although brief, "you will never amount to anything" has haunted me for a significant period of my life. The imprint of white individualism has also been well engrained creating for myself a life of dichotomous existence. I will generalise in suggesting that this type of 
existence has been typical for many Maori, as statistics for Maori continually portrays me, through the label as someone "who will never amount to anything". The hidden agenda of being a Māori

Smith states that to counter this way of thinking is to become 'conscious' or to 'conscientize' ourselves about our experience. There is the need to ask critical questions of ourselves at three critical sites of engagement namely conscientisation, resistance and transformative action. The teaching team experienced marae as a teaching space as key to activating these critical sites of engagement. It is at the centre of learning where conscientisation, resistance and transformative action occur simultaneously, a place that provides the space for tauira and kaiako to approximate their reality. What Maori Marsden (2003, p. 27) refers to as the centre and where:

A person must create for himself an orderly system of ideas about himself and his universe in order to give direction and purpose to his life. From that centre derives his basic convictions about the meaning and purpose of life in general and he will exhibit a sureness of touch that comes from inner clarity.

When incorporated with indigenous epistemology and pedagogy within a social work curriculum, social work graduates are being prepared to work with indigenous people, families, tribes and others.

\section{Conclusion}

Some key findings of this research highlight:

1. The significance of the learning environment located at marae creates the space for pedagogy informed by the social order and cultural truth of Tangata Whenua. The Education Act (1989) provides a legal mandate for Wānanga to privilege "āhuatanga Māori according to tikanga Māori". Marae, according to the participants enabled a space for Tauiwi and Māori who are connected to marae or disconnected from their own world, to form relationships with each other.

2. There is need for all kaiako to have a reconciled understanding of their own positioning in this relationship to transformation. In particular for Pākehā kaiako, a clear understanding of 'white privilege' and the role we play in it. That Mãori have obligations to a relationship with this place many hundreds of years before ours. That Pākehā and other tauiwi are able to articulate and navigate the contestations that exist in validating a Māori world view, as determined by Māori, in social work education, social work practice and the wider world.

3. The relationship established with kaiako is a critical component to the learning experience and transferring of learning gained. In particular, principled engagement requires courage of heart, shared vision and collective action. Relationships with fellow tauira as well as with haukāinga (local people) were also identified as significant to the learning experience. The significance of the ongoing nature of the relationship with kaiako alongside peers, post-graduation also emerged through the research process.

4. The importance of a shared vision in the collective leadership of the programme. For each member of the teaching team a sharp critical consciousness of our own worldview positioning and a conscious awareness of how this supports individual contributions to the learning environment was considered critical. The significance of the activation of this in the practise of all team members was a consistent message in participant responses.

In conclusion, this research has highlighted a particular approach to social work education that despite current global trends of social work education, practice and research internationally, provides evidence that social work learning can occur in a traditionally cultural space such as the Marae, as valid and appropriate to a true bicultural relationship and principle based social work practice. This research began as a response to Hariata and Taina Pohatu' call for the consolidation of our degree and as a consideration for the development of the four-year degree.

We are grateful for Danny's contribution to this with us all; that he was able to draw from his own centre of his universe, Ngāmaihi, Tūteao Marae, Te Teko, to transcend what he calls "the hidden agenda of being Maori"; for his dedicated commitment to the belief that all people, both from dominant and targeted groups, have a critical role in dismantling oppression and generating a vision for a socially just future and last but not least his tireless efforts in taking care of what Freire $(1993$, p. 26) asserts as "the great humanistic and historical task of the oppressed; to liberate themselves and the oppressor as well". You have been an inspiring hoa haere. Thank you for your valued companionship.

To conclude, Tāwhiao made the following proclamation "Māku e hanga tōku whare, ko te tāhuhu ko hīnau, ko ngā pou ko māhoe, ko patatē" (I will build my own house and it will be constructed with a range of material). Within this context, Tāwhiao affirms the importance for structures, such as Marae, to be recognised as a space that Maori can claim as their own, a space, unburdened by eurocentric impositions within social work. The textures of the Marae structure offer learning that is felt, in the head, the heart and Te Kaharoa, vol. 12, 2019, ISSN 1178-6035 
in their relationships within their own whānau. Additionally as indicated by the participants, this can provide a safe environment for tauiwi to explore themselves, their relationship with and to tangata whenua so as to begin bicultural and ethical social work practice. 


\section{Te Rarangi Pukapuka: References}

Asher, N. (2009). Writing home/decolonizing texts. Discourse:Studies in the Cultual Politics of Education, 30(1), 1-13.

Freire, P. (1993). Pedagogy of the Oppressed. New York, NY: The Continuum publishing Company.

Gramsci, A. (1971). Selections from the Prison Notebooks. In $Q$ Hoare \& G Nowell Smith (Eds). London, England: Lawrence and Wishart.

Haerewa, N. (2017). Māori Culture: What Is A Marae? Retrieved from https://theculturetrip.com/pacific/newzealand/articles/Maori -culture-what-is-a-marae/

Johnston, P. (1998). He Ao Rereke. Education Policy \& Maori under-achievement: Mechanisms of Power \& Difference. Auckland, New Zealand: Thesis Doctor of Philosophy in Education, University of Auckland.

McLennan, M (2010) Maori spirituality and spiritual direction. A special Interest project submitted in partial fulfillment of the requirements of the spiritual directors Formation Programme of Spiritual Growth Ministries.

Ohia, M. R. (2006). Towards A Values-Based Transformation Movement for Maori Advancement - The Case for Spiritual, Ethical and Moral Imperatives Within Maori Transformational Movements. Auckland, New Zealand: Auckland University (unpublished).

O'Sullivan, D. (2007). Beyond Bi-culturalism. The Politics of an Indigenous Minority. Wellington, New Zealand: Huia Publishers.

Pohatu, T. (2008). Takepū: principled approaches to healthy relationships, Proceedings of the Traditional

Knowledge Conference, Te Tatau Pounamu: The Greenstone Door, ISBN 0- 9582610-8-3.

Royal, T. C. (2003). The Woven universe: Selected writings of Rev. Māori Marsden. Otaki, New Zealand: The Estate of Rev. Māori Marsden.

Smith, G. (2003). Kaupapa Maoori Theory - Theorizing Indigenous Transformation of Education and Schooling. Kaupapa Māori Sympososium. NZARE/AARE Joint conference. Auckland: University of Auckland and Te Whare Wananga o Awanuiarangi. 
Te Wananga o Aotearoa. (2013). Version 1, HASW 504604 704). Te Tohu Paetahi nga Poutoko Whakarara Oranga Degree in Social work (Bi-culturalism in Practice). Marau document .

Walker, R. (1990). Ka Whawhai Tonu Matou Struggle Without End. Auckland, New Zealand: Penguin Books (NZ) Ltd.

Williams, A.D. (2008). Inside the divine pattern. Canada: Gemini 11 Inc. 